\title{
Stroke Incidence and Demographic Properties of Patients in
} Ardahan Province Ardahan İlinin İnme İnsidansı ve İldeki İnme Hastalarının Demografik Özellikleri

(1) Mehmet Hamamc1

Bozok University Faculty of Medicine, Department of Neurology, Yozgat, Turkey

\begin{abstract}
Objective: This study aimed to evaluate the demographic, etiologic, and clinical characteristics of patients with the diagnosis of stroke, as well as the incidence of stroke in Ardahan province, which is the gateway from our country to the Caucasus (Caucasia).

Materials and Methods: This study has a descriptive design. The hospital records of patients who were diagnosed as having stroke or cerebrovascular disease between June 2015 and June 2016 in Ardahan State Hospital were retrospectively investigated.

Results: In the defined one year period, 196 individuals were admitted to our hospital with the diagnosis of acute stroke. The incidence of stroke was $199 / 100.000$ per person-year. Of these patients, $71.4 \%(n=140)$ were diagnosed as having ischemic stroke and $20.4 \%(n=40)$ had hemorrhagic stroke. The incidence of ischemic stroke was determined as 142/100.000 per person-year. The incidence of hemorrhagic stroke was determined as 41/100.000 per person-year. Ipsilateral muscle weakness was the most common symptoms in $78.1 \%(\mathrm{n}=153)$ of the patients. Of the patients, $3.6 \%(\mathrm{n}=7)$ were admitted to the hospital within 3 hours after the onset of symptoms and $75.5 \%(\mathrm{n}=148)$ were brought to our hospital by ambulance

Conclusion: Although the results of this study are generally compatible with other studies in the literature, they also show differences. The incidence of stroke in our country and the demographic characteristics of patients with stroke differ from other countries, at the same time there may be regional differences. For this reason, the data in this study are important because they provide information about our country and its northeastern region.
\end{abstract}

Keywords: Stroke, epidemiology, incidence, cerebral infarction, cerebral hemorrhage

$\ddot{O} \mathbf{z}$

Amaç: Türkiye'nin Kafkaslara açılan kapısı konumunda olan Ardahan ilinin inme insidanslarını hesaplama, inme hastalarını demografik, etiyolojik, klinik özellikleri ve risk faktörleri açısından inceleyerek ülkemizin akut inme verilerine katkıda bulunma amaçlandı.

Gereç ve Yöntem: Tanımlayıcı nitelikteki bu çalışmada Ardahan Devlet Hastanesi'nde Haziran 2015 ile Haziran 2016 tarihleri arasında inme veya beyin damar hastalığı tanısı alan hastaların hastane kayıtları geriye dönük olarak incelenmiştir.

Bulgular: Bir yıllık sürede hastanemize 196 kişinin akut inme tanısıyla başvurduğu tespit edildi. İlin inme insidansı yıllık 199/100.000 kişi-yıl olarak tespit edildi. Bu hastaların \%71,4’ü $(\mathrm{n}=140)$ iskemik, \%20,4’ü $(\mathrm{n}=40)$ hemorajik inme tanıs1 ald1. İskemik inme insidans1 y1llık 142/100.000 kişi-yıl, hemorajik inme insidansı yıllık 41/100.000 kişi-yıl olarak tespit edildi. Olguların \%78,1'inde ( $\mathrm{n}=153)$ tek taraflı kas güçsüzlüğü en sık başvuru şikayeti olarak tespit edildi. Hastaların \%3,6'sının ( $\mathrm{n}=7)$ şikayetleri başladığı andan itibaren 3 saat içinde hastaneye başvurduğu ve \%75, 5'inin ( $\mathrm{n}=148)$ ambulans ile hastanemize getirildiği saptandi.

Sonuç: Bu çalışmanın bulguları literatürdeki diğer çalışmalarla genel olarak uyumlu olmakla birlikte farklılıklar da göstermektedir. Bunun nedeni ülkemizin inme görülme oranlarının ve inme hastalarının demografik özelliklerinin diğer ülkelerden farklılık göstermesiyle birlikte bölgesel farklılıkların da görülebilmesidir. Bu sebeple veriler ülkemiz ve ülkemizin kuzeydoğu bölgesi açısından önem arz etmektedir.

Anahtar Kelimeler: İnme, epidemiyoloji, insidans, serebral enfark, serebral hemoraji

Address for Correspondence/Yazışma Adresi: Mehmet Hamamcı MD, Bozok University Faculty of Medicine, Department of Neurology, Yozgat, Turkey Phone: +90 5062985757 E-mail: drmehmetmehmet@gmail.com ORCID: orcid.org/0000-0001-7100-3952

Received/Geliş Tarihi: 21.12.2018 Accepted/Kabul Tarihi: 12.02.2019

${ }^{\circ}$ Copyright 2019 by Turkish Neurological Society

Turkish Journal of Neurology published by Galenos Publishing House. 


\section{Introduction}

Stroke is a sudden emerging focal or generalized neurologic deficit of vascular origin (1). It is the second most common cause of death after coronary heart diseases in the world and in our country $(2,3)$. It is the third most common cause of disability in our country (4). The incidence of stroke varies among countries and among different regions in the same country $(3,5)$. In terms of epidemiologic and incidence data, Western sources are often consulted. The prevalence of stroke in Turkey and the distribution of subtypes differ from Europe and the United States of America, and there may also be regional differences in Turkey (6).

Ardahan, which is Turkey's gateway to the Caucasus, is at the bottom of the list of development among the provinces of Turkey. Ardahan is a province located in the transition region between the countries due to the presence of Armenia in the east and Georgia in the north (7). The population of Ardahan was 98,335 in 2015. Considering the population structure of Ardahan, it is observed that the majority of the population live in rural areas. In the province where 252 settlements are located, $80 \%$ of the population lives outside the city. In fact, approximately $65 \%$ of the population in the province lives in villages. Ardahan exhibited a negative growth in a recent census. The majority of the migration across Ardahan constitutes individuals of working age. This led to an increase in the elderly population in the province $(7,8,9)$.

One of the most important reasons for migration is that the winter climate of the province is harsh and lasts a long time (7). Because of this situation, the people who come to visit their relatives and homeland in the summer create significant differences in the population in the province between the summer and winter seasons.

Although stroke takes second rank among the causes of death and is third among the causes of morbidity, few studies have investigated the demographic, epidemiologic, and clinical characteristics of patients with stroke in our country. There are no studies about the incidence of stroke in Turkey or in Ardahan in the literature. The Ardahan State Hospital is the only treatment center for patients with acute stroke in the province and the only center that has the authority to refer patients with stroke out of the province. Therefore, the stroke data of the Ardahan State Hospital reflect all stroke data of the province.

In this study, it was aimed to calculate the incidence of patients with acute stroke, to determine the etiologic, epidemiologic, seasonal distribution, demographic, and clinical characteristics of patients with stroke in the Ardahan State Hospital between 2015 and 2016, and to contribute to our country's and the World's acute stroke data.

\section{Materials and Methods}

This descriptive study was planned retrospectively. Between June 2015 and June 2016, 196 patients who were diagnosed as having stroke were retrospectively reviewed. This study was approved by the Ethics Committee of Bozok University (2017KAEK-189_2018.09.12_04). A privacy statement was signed for the patients in the study and permission was received for the use of the patients' data.
All ICD-10 codes related with stroke were scanned in the hospital's data system in order to reach the information of the patients. Between June 2015 and June 2016, 1326 file numbers, which received one of the stroke codes, were identified. Patients with chronic stroke were excluded and the last admission of patients with more than one admission to the hospital due to acute stroke were included. In this study, 196 patients who were diagnosed as having acute stroke were included in the study. The data of these patients were analyzed in hospital data records and patient file archives. The data records and patient files recorded by the emergency, neurology, and neurosurgery departments of 196 patients admitted for acute stroke were evaluated primarily. For data that could not be accessed from these records, data records and patient files recorded by chest diseases, internal medicine, and cardiology departments at the same time were analyzed. The lipid panel could not be evaluated in patients who were referred because it is not measured in the emergency department.

According to ischemic stroke localization, patients were divided into 4 groups involving the anterior cerebral artery, middle cerebral artery, posterior cerebral artery, and internal carotid artery (ICA) areas. According to hemorrhagic stroke localization, patients were divided into 5 groups involving basal ganglia, thalamus, lobar, cerebellar and brainstem. The patients were grouped according to age, sex, concomitant diseases, and type of access to the emergency department. The patients were evaluated for stroke risk factors as defined by the American Heart Association/American Stroke Association (10). The incidence of stroke in the seasons, hospitalization durations, and mortality rates were analyzed. Patients were divided into four subgroups involving patients aged $\leq 45$ years, 46-65 years, $65-75$ years, and $>75$ years. Arterial blood pressure was measured at the time of arrival. Patients were divided into three groups according to their initial measurements involving patients with hypertension (systolic $>140 \mathrm{~mm} \mathrm{Hg}$, diastolic $>90 \mathrm{~mm} \mathrm{Hg}$ ), with normotension (systolic $=90-140 \mathrm{~mm} \mathrm{Hg}$, diastolic $=60-90 \mathrm{~mm} \mathrm{Hg}$ ) and with hypotension (systolic $<90 \mathrm{~mm} \mathrm{Hg}$, diastolic $<60 \mathrm{~mm} \mathrm{Hg}$ ).

\section{Statistical Analysis}

The Statistical Package for the Social Sciences (SPSS 21.0) was used for statistical analysis. Descriptive statistics were given. Student's t-test was used to compare groups with normal distribution and the Mann-Whitney $U$ test was used to compare groups without normal distribution. One-way analysis of variance was used to compare multiple groups. The chi-square test was also used to compare multiple groups. A p value of $<0.05$ was considered statistically significant.

\section{Results}

One hundred ninety-six patients with stroke who were admitted to our hospital in the one-year period were included in the study. These patients consisted of 140 patients with ischemic stroke, 40 with hemorrhagic stroke, 11 with transient ischemic attack, and 5 with subarachnoid hemorrhage.

Demographic data, risk factors, and symptoms at the time of arrival of patients with stroke are shown in Table 1. The statistical comparison of the risk factors for ischemic stroke and hemorrhagic stroke is presented in Table 2. 
Table 1. Demographic data, risk factors, and symptoms at admission of the patients with stroke

\section{Demographic data}

All patients with ischemic stroke $(\mathrm{n}=196)$ n (\%)

Mean age of patients with ischemic stroke

$75.09 \pm 13.701$

$\leq 45$ years

3 (2.1)

46-65 years

27 (19.3)

65-75 years

39 (27.9)

$>75$ years

$71(50.7)$

Mean age of patients with hemorrhagic

$69.70 \pm 13.667$

stroke

$\leq 45$ years

2 (5)

46-65 years

12 (30)

65-75 years

10 (25)

$>75$ years

16 (40)

Mean age of patients with transient

$66.73 \pm 14.880$

ischemic attack

$\leq 45$ years

$1(9.1)$

46-65 years

4 (36.4)

65-75 years

2 (18.2)

$>75$ years

4 (36.4)

Mean age of patients with hemorrhagic

$61.80 \pm 9.39$

stroke

$\leq 45$ years

$0(0)$

46-65 years

$3(60)$

65-75 years

2 (40)

$>75$ years

0 (0)

Sex distribution of patients with ischemic stroke

Female

65 (46.4)

Male

75 (53.6)

Sex distribution of patients with hemorrhagic stroke

Female

19 (47.5)

Male

$21(52.5)$

Sex distribution of patients with transient ischemic attack

Female

7 (63.6)

Male

4 (36.4)

Sex distribution of patients with subarachnoid hemorrhage

Female

2 (40)

Male

$3(60)$

Risk factors of patients with stroke

Hypertension

121 (61.7)

Diabetes mellitus

52 (26.5)

History of cardiac disease

49 (25)

Cigarette smoking

46 (23.5)

History of stroke

$26(13.3)$

\section{Table 1. Continued}

Demographic data

All patients with ischemic stroke

$(\mathrm{n}=196)$

n $(\%)$

Symptoms of patients with stroke at admission

Unilateral muscle weakness

$153(78.1)$

Loss of consciousness

$61(31.1)$

Speech disturbance

60 (30.6)

Vertigo

$31(15.8)$

Visual disturbance

$8(4.1)$

Table 2. Comparison of risk factors in patients with ischemic and hemorrhagic stroke

\begin{tabular}{|llll|} 
& $\begin{array}{l}\text { Ischemic } \\
\text { stroke }\end{array}$ & $\begin{array}{l}\text { Hemorrhagic } \\
\text { stroke }\end{array}$ & \\
$\mathbf{n}(\%)$ & $\mathbf{n}(\%)$ & $\mathbf{p}$ \\
Hypertension & $87(62.1)$ & $26(65)$ & 0.885 \\
$\begin{array}{l}\text { Diabetes mellitus } \\
\begin{array}{l}\text { History of cardiac } \\
\text { disease }\end{array}\end{array}$ & $40(28.6)$ & $8(20)$ & 0.380 \\
$\begin{array}{l}\text { Cigarette smoking } \\
\text { History of stroke }\end{array}$ & $34(24.3)$ & $6(15)$ & 0.171 \\
\hline
\end{tabular}

The incidence of stroke was $199 / 100,000$ person-years. The incidence of ischemic stroke was 142/100,000 person-years. The incidence of ischemic stroke in men was 147/100,000 person-years and was 137/100,000 in women. When the incidence of ischemic stroke was evaluated by age, it was $5 / 100,000$ person-years in those aged under 45 years, 523/100,000 person-years between the ages of 65 and 75 years, and 912/100,000 person-years in those aged over 65 years. The incidence of hemorrhagic stroke was 41/100,000 person-years. The incidence of hemorrhagic stroke in men was $37 / 100,000$ person-years and was 44/100,000 person-years in women. When the incidence of hemorrhagic stroke was evaluated by age, it was 3/100,000 person-years in those aged under 45 years and 315/100,000 person-years in patients aged over 65 years.

The seasonal distribution of the patients is shown in Graph 1. Hypertension was detected in $62.8 \%(n=123)$ of the patients, hypotension in $8.7 \%(n=17)$, tachycardia in $19.4 \%(n=38)$, and bradycardia in $2.6 \%(n=5)$. In patients with hypertension, $48 \%$ $(\mathrm{n}=59)$ had systolic arterial pressure of $>180 \mathrm{~mm} \mathrm{Hg}$ or diastolic arterial pressure of $>110 \mathrm{~mm} \mathrm{Hg}$ at the time of admission to the emergency department. The electrocardiogram of patients with ischemic stroke showed normal sinus rhythm in 65\% ( $n=91)$, atrial fibrillation (AF) in $32.9 \%(n=46)$, and pace rhythm in three patients.

When the results of the neurologic examinations were evaluated, hemiparesis or hemiplegia was detected in $76 \%$ $(\mathrm{n}=149)$ of patients, and quadriparesis was detected in three patients. Aphasia or dysarthria were found in $31.6 \%(n=62)$ of patients, disturbance of consciousness in $28.6 \%(n=56)$, dysmetria 


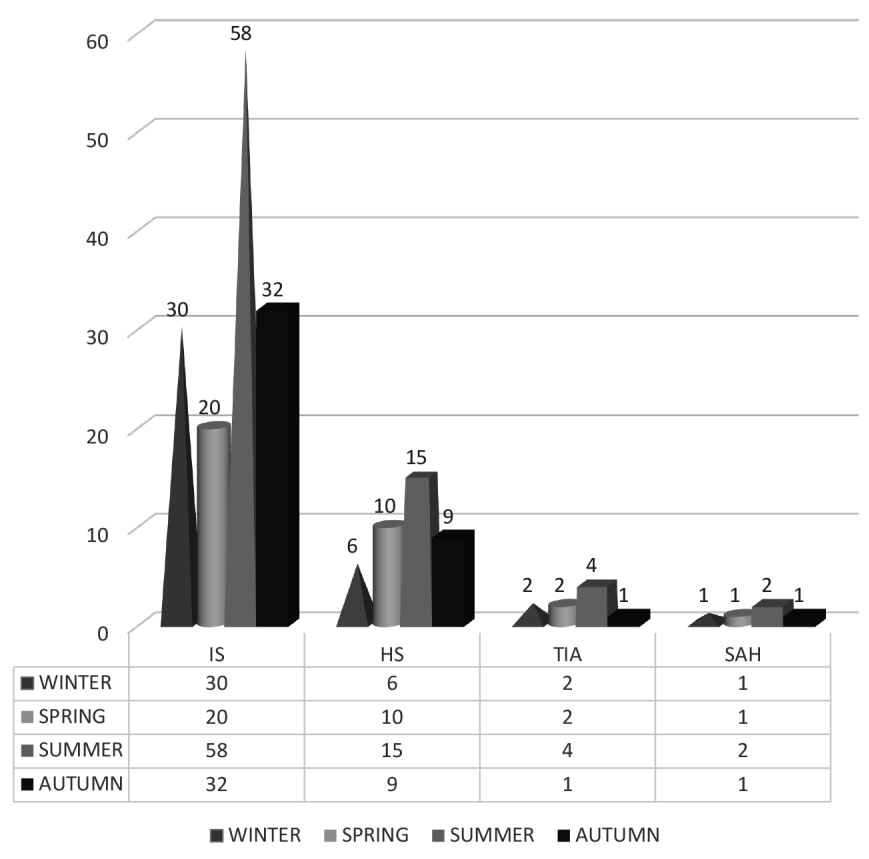

Graphic 1. Distribution of patients with stroke according to the seasons IS: Ischemic stroke, HS: Hemorrhagic stroke, TIA: Transient ischemic attack, SAH: Subarachnoid hemorrhage

or dysdiadochokinesia were detected in $11.2 \% \quad(\mathrm{n}=22)$, and $9.7 \%(n=19)$ of the patients had normal neurologic examination findings.

Of the patients with ischemic stroke, 7.9\% $(\mathrm{n}=11)$ had infarction in the territory of the anterior cerebral artery, $77.1 \%$ $(n=108)$ of the middle cerebral artery, $13.6 \%(n=19)$ of the posterior cerebral artery, and $1.4 \%(n=2)$ ogf the ICA. Of the patients with hemorrhagic stroke, $45 \%(n=18)$ had basal ganglia hematoma, $22.5 \%(n=9)$ thalamic hematoma, $17.5 \%(n=7)$ lobar hematoma, $7.5 \%(\mathrm{n}=3)$ brain stem hematoma, and $7.5 \%(\mathrm{n}=3)$ had cerebellar hematoma.

Seven $(3.6 \%)$ patients were admitted to the hospital within 3 hours of the onset of symptoms. One hundred forty-eight (75.5\%) patients were brought to our hospital by ambulance.

Of the patients with ischemic stroke, $31.4 \%(n=44)$ were hospitalized in the intensive care unit (ICU) and $58.6 \%(n=82)$ in the neurology ward. Of the patients with ischemic stroke, $8.6 \%(n=12)$ were referred to another hospital due to a lack of room in the ICU. Of the patients with hemorrhagic stroke, $72.5 \%(n=29)$ were hospitalized in the ICU and $12.5 \%(n=5)$ in the neurology ward. Of the patients with hemorrhagic stroke, $15 \%(n=6)$ were referred to another center due to a lack of room in the ICU. Four patients $(2 \%)$ voluntarily went to another center.

The median duration of hospitalization of patients with ischemic stroke was 14 (range, 1-129) days and it was 16 (range, 1-116) days in patients with haemorrhagic stroke. There was no significant difference between patients with ischemic and hemorrhagic stroke in terms of duration of hospitalization $(\mathrm{p}=0.784)$.
The mortality rate was $18.6 \%(\mathrm{n}=23)$ in patients with ischemic stroke and $26.5 \%(\mathrm{n}=9)$ in patients with hemorrhagic stroke during hospitalization. In all patients with stroke, the mortality rate in those aged under 65 years was $9.5 \%(n=4)$ and $22.5 \%$ $(n=29)$ in patients aged over 65 years.

The mean age of the patients who died was $79.09 \pm 12.92$ years and the mean age of the patients who were discharged was $72.25 \pm 14.11$ years; this difference was statistically significant $(\mathrm{p}=0.010)$. There was no correlation between mortality rates and the season of hospitalization $(\mathrm{p}=0.593)$.

\section{Discussion}

Studies of epidemiology, incidence, and demographic characteristics are not sufficient in Turkey, even in common diseases such as stroke. In some provinces, this type of study is even less. It is not very healthy for our country, which is the intersection point of Europe, Asia, and Africa, to use data from other continents. The importance of stroke is increasing in our country where the old population is increasing.

The risk of stroke increases as age increases. After the age of 55 years, it is stated that the risk of stroke increases 2 -fold in every decade $(3,11)$. Studies have reported that about $70 \%$ of patients with stroke are aged over 65 years $(6,12)$. Altun et al. (6) reported the mean age of ischemic stroke as 72.47 years and the mean age of hemorrhagic stroke as 65.74 years. İnanç et al. (13) reported the mean age of ischemic stroke as 68.62 years and the mean age of hemorrhagic stroke as 64.73 years. In our study, $78.6 \%$ of patients with ischemic stroke and $65 \%$ of patients with hemorrhagic stroke were aged over 65 years, and the mean age of patients with ischemic and hemorrhagic stroke was 75.09 years and 69.70 years, respectively. In this study, the mean age was higher than in other studies. This could be because migration in Ardahan mostly involves young people of working age and indirectly the older population is increasing.

In the literature, the incidence of stroke was reported as $30-120 / 100,000$ person-years in people aged 35-44 years, and $670-970 / 100,000$ person-years in people aged 65-75 years (14). In another study, the incidence of stroke was 170-360/100,000 person-years in people aged 55-64 years, 490-890/100,000 person-years in people aged 65-74 years, and 1350-1790/100,000 person-years in people aged over 75 years (15). Nencini et al. (16) showed that the incidence of stroke was 10/100,000 personyears in people aged 15-45 years. In another study, the incidence of stroke in people younger than 45 years was 3.4-11.3/100,000 person-years (17). The data in this study were generally consistent with those in the literature with minor differences.

The incidence of ischemic stroke in the literature was 133/100,000 person-years in men and 99/100,000 person-years in women. The incidence of hemorrhagic stroke was $65 / 100,000$ person-years in men and 46/100,000 person-years in women (18). In this study, the incidence of hemorrhagic stroke in women was slightly higher than in men. The slight differences in this study may be due to racial, cultural, and geographic backgrounds. Further studies are needed in our country in this regard.

About $90 \%$ of stroke risk factors are modifiable risk factors. This suggests that $90 \%$ of stroke is preventable (3). The most 
common risk factors for stroke are hypertension, diabetes mellitus, and heart disease $(6,19)$. In this study, similar to other studies, it was found that hypertension $(61.7 \%)$, diabetes mellitus $(26.5 \%)$, and known heart disease $(25 \%)$ were the most common risk factors in patients with stroke.

AF is very important because it increases the risk of ischemic stroke by about 5 -fold. AF is seen in $1.5 \%$ of patients aged between 50 and 59 years and $23.5 \%$ between those aged 80 and 89 years $(1,20)$. The incidence of AF increases gradually with age, and as the age progresses, the risk of AF-related stroke increases gradually $(1,10)$. In this study, AF was detected in $32.9 \%$ of patients and this result was slightly higher than the reported studies from Turkey. In light of this information, the high rate of AF in our study could be due to the high mean age in our study.

The symptoms of patients with stroke at admission may vary. Altun et al. (6) and Kiyan et al. (20) reported the most common symptom in their studies as unilateral muscle weakness. In these studies, speech disturbance was the second most frequently reported symptom. Similar to the results of those two studies, the most common symptom was unilateral muscle weakness in our study. However, in this study, the second most frequent symptom was disturbance of consciousness and the third most frequent symptom was speech disturbance. The difference in the second most frequent symptom in this study might be due to the poor socioeconomic conditions in Ardahan and due to the fact that most of the population was living outside of the province. Also, the overall situation of the patients could have deteriorated until they could reach the hospital, or that the average age of the patients was higher in our study than others.

The most frequent neurologic examination finding in patients was reported as hemiplegia and hemiparesis in previous studies $(20,21)$. Our results supported the findings of those studies. Altun et al. (6) found that $23.5 \%$ of patients presented with loss of consciousness in their study performed in the Southeast of Turkey, which was different compared with other studies. In our study, $31.1 \%$ of patients were admitted. This study supports other studies on this subject. Loss of consciousness was different from other studies in Altun et al.'s study (6). In this study, $31.1 \%$ of the patients were admitted with loss of consciousness. This may be due to people in low socioeconomic levels giving less attention to findings other than loss of consciousness.

Due to its high altitude, Ardahan is one of the coldest provinces of Turkey. Summers are cool and winters are long and hard in Ardahan (8). Slatina et al. (22) showed that seasonal changes had no effect on stroke frequency. However, in two studies from Turkey, ischemic stroke was more frequent in the summer months $(6,23)$. Anlar et al. (23) observed that hemorrhagic stroke was most frequent in the summer season, whereas Altun et al. (6) observed that hemorrhagic stroke was most frequent in the autumn season. In our study, we observed that ischemic and hemorrhagic stroke were more frequent in the summer. This difference may be due to the change in the population of the province in the summer and autumn rather than the change in temperature.

In the literature, the rate of admission to hospital in the first 3 hours in patients with ischemic stroke was found to be between $2.2 \%$ and $48 \%(6,20,24)$. In this study, the rate of admission to hospital in the first 3 hours in patients with ischemic stroke was $3.6 \%$. One of the reasons for this difference was the low socioeconomic conditions in the province and loss of time before reaching the hospital due to the fact that most of the population of the province lived in villages.

Ç1 ğşar and User (21) reported that $14.9 \%$ of patients were transferred to the emergency department by ambulance, whereas Altun et al. (6) reported that this rate was 58.6\%. In this study, $75.5 \%$ of patients were brought to our hospital by ambulance. In studies in Turkey; Çı ğşar and User (21), $14.9 \%$ of patients in their study, Altun et al. (6), $58.6 \%$ of patients in their study came to the emergency department by ambulance. The high rate of transporting by ambulance in our study might also be due to the fact that the majority of the population was out of the city centre and the difficulty of transportation in some places because of the high altitude of the province.

In the literature, studies conducted in tertiary centres showed that one-year mortality rates were around $25-30 \%(25,26)$. The rate of early death in developing countries was $25 \%$ higher (27). Şahin et al. (28) showed that the mortality rate in hemorrhagic stroke was $34.1 \%$ and the mortality rate in ischemic stroke was $13.3 \%$. In this study, the mortality rate was $18.6 \%$ in ischemic stroke and $26.5 \%$ in hemorrhagic stroke, in accordance with the literature.

\section{Study Limitations}

The lack of data of obesity, metabolic syndrome, and hyperlipidemia in this study is a limitation of this study. Therefore, new studies are needed to evaluate those variables.

\section{Conclusion}

As a result, this study showed that the risk factors of cerebrovascular diseases in Ardahan have similarities with many different populations. The geographic and socioeconomic characteristics of the region can cause a significant amount of delay in the treatment of patients. This study draws attention to the significant effects of migration on data in the field of health. This study also highlighted that the prevalence of stroke is increasing in the world and in our country every year, and that it is important to combat the risk factors. The province of Ardahan, which has an increasing elderly population due to migration, may shed light on the future epidemiologic data of Turkey.

\section{Ethics}

Ethics Committee Approval: This study was approved by the Ethics Committee of Bozok University (2017-KAEK189_2018.09.12_04).

Informed Consent: Consent form was filled out by all participants.

Peer-review: Externally and internally peer-reviewed.

Financial Disclosure: The author declared that this study received no financial support.

\section{References}

1. Benjamin E, Virani S, Callaway C, et al. Heart disease and stroke statistics-2018 update: a report from the American Heart Association Circulation 2018;137:67-492.

2. Feigin VL, Krishnamurthi RV, Parmar P, et al. Update on the global burden of ischemic and hemorrhagic stroke in 1990-2013: the GBD 2013 study. Neuroepidemiology 2015;45:161-176. 
3. Kablan Y. İnme: Epidemiyoloji ve Risk Faktörleri. Turkiye Klinikleri Neurology-Special Topics. 2018;11:1-19.

4. Ozturk S. Epidemiology and the Global Burden of Stroke--Situation in Turkey. World Neurosurg 2014;81:35-36.

5. Broderick JP, Phillips SJ, O'Fallon WM, Frye RL, Whisnant JP. Relationship of cardiac disease to stroke occurrence, recurrence, and mortality. Stroke 1992;23:1250-1256.

6. Altun Y, Aydın İ, Algın A. Adıyaman İlinde İnme Tiplerinin Demografik Özellikleri. Turk J Neurol 2018;24;26-31.

7. Topcuoğlu A, Oral IO, Demir M. Ardahan ilinin sosyoekonomik yapısının görünümü. ArdahanÜniversitesi İktisadi ve İdari Bilimler Fakültesi Dergisi 2016:131-142.

8. Akbulak C. Ardahan ilinde kırsal turizm potansiyelinin sayısallaştırılmış swot analizi ile değerlendirilmesi. Humanitas Uluslararası Sosyal Bilimler Dergisi 2016;7:1-30.

9. TUIK, Adrese Dayalı Kayıt Sistemi (ADKNS) 2015 yılı sonuçları. Erşim tarihi:10 Ekim 2018 http://tuikapp.tuik.gov.tr/adnksdagitapp/adnks.zul

10. Goldstein LB, Bushnell CD, Adams RJ, et al. Guidelines for the primary prevention of stroke: a guideline for healthcare professionals from the American Heart Association/American Stroke Association. Stroke 2011;42:517-584.

11. Boehme AK, Esenwa C, Elkind MS. Stroke risk factors, genetics, and prevention. Circ Res 2017;120:472-495.

12. Soyuer F, Ünalan D, Öztürk A. İnme hastalarında yaş ve cinsiyetin fonksiyonel yetersizlik üzerine olan etkisi. İnönü Üniversitesi Tip Fakültesi Dergisi 2007; 14:91-94.

13. İnanç $Y, A y H$, İnanç $Y$, et al. Şanlıurfa ilinde inme tiplerinin demografik özellikleri. J Clin Anal Med 2015;6:257-260.

14. Ovbiagele B, Nguyen-Huynh MN. Stroke epidemiology: advancing our understanding of disease mechanism and therapy. Neurotherapeutics 2011;8:319-329.

15. Hankey GJ. Stroke how largea public health problem and how can the neurologist help. Arch Neurol 1999;56:748-754.
16. Nencini P, Intizari D, Baruffi MC, et al. Incidence of stroke in young adults in Florence, Italy. Stroke 1988;19:977-981.

17. Kristensen B, Malm J, Carlberg B, et al. Epidemiology and etiology of ischemic stroke in young adults aged 18 to 44 years in northern Sweden. Stroke 1997;28:1702-1709.

18. Feigin VL, Norrving B, George MG, Foltz JL, Roth GA, Mensah GA. Prevention of stroke: a strategic global imperative. Nat Rev Neurol 2016;12:501-512.

19. Yalçın E, Yalçın M, Çelik Y, Ekuklu G. Risk factors for recurrent ischemic stroke in Turkey. Balkan Med J 2008;25:117-23.

20. Kıyan S, Özsaraç M, Ersel M, Aksay E, Yürüktümen A, Musalar E. Acil Servise Başvuran Akut İskemik İnmeli 124 Hastanın Geriye Yönelik Bir Yillık İncelemesi. Eurasian J Emerg Med 2009;8:15-20.

21. Çı̆̆şar G, User NN. Acil Servise Başvuran Akut İnmeli Hastaların Analizi. Kafkas J Med Sci 2015;5:6-12.

22. Slatina E, Music M, Babic N, et al. Correlation between change in air humidity and the incidence of stroke. Materia Sociomed 2013;25:242-245.

23. Anlar O, Tombul T, Unal O, Kayan M. Seasonal and environmental temperature variation in the occurrence of ischemic strokes and intracerebral hemorrhages in a Turkish adult population. Int J Neurosci 2002;112:959-963.

24. Lacy CR, Suh DC, Bueno M, Kostis JB. Delay in presentation and evaluation for acute stroke: Stroke Time Registry for Outcomes Knowledge and Epidemiology (STROKE). Stroke 2001;32:63-69.

25. Cabral NL, Muller M, Franco SC, et al. Three-year survival and recurrence after first-ever stroke: the Joinville stroke registry. BMC Neurol 2015;15:70.

26. Sun Y, Lee SH, Heng BH, Chin VS. 5-year survival and rehospitalization due to stroke recurrence among patients with hemorrhagic or ischemic strokes in Singapore. BMC Neurol 2013;13:133.

27. Mukherjee D, Patil CG. Epidemiology and the global burden of stroke. World Neurosurg 2011;76:85-90.

28. Şahin AD, Üstü Y, Işık D, Öztaş D, Eray İK, Uğurlu M. Serebrovasküler Hastalık Geçiren Hastaların Demografik Özellikleri ve Birinci Basamak Sağlık Merkezlerinde Önlenebilir Risk Faktörlerinin Değerlendirilmesi. Ankara Med J 2015;15:196-208. 